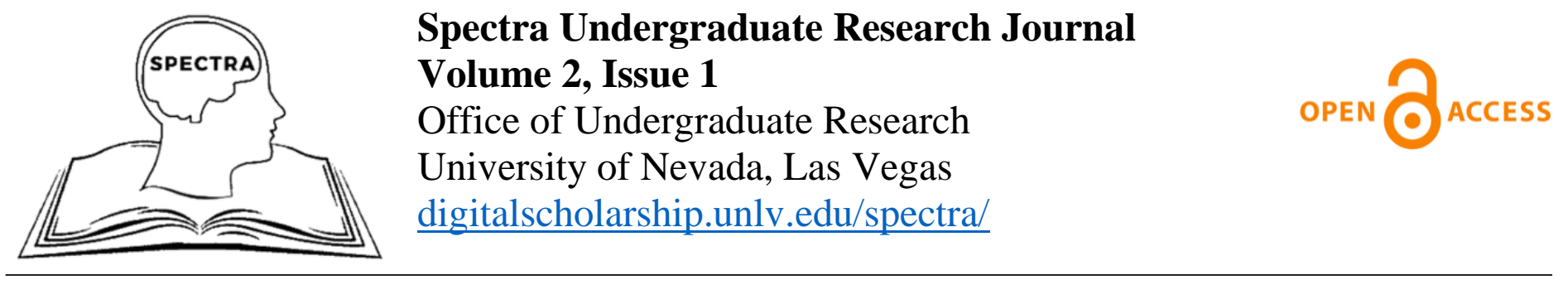

\begin{tabular}{|c|}
\hline Category \\
\hline Arts, Humanities, and Social Sciences $>$ Social Sciences $>$ Political Science \\
\hline Received \\
\hline December 13,2021 \\
\hline Accepted \\
\hline February 18,2022 \\
\hline Published \\
\hline February 28,2022 \\
\hline Article Title \\
\hline The Gender Wage Gap as it Relates to State Partisan Control and Pay Equity Policy \\
\hline Authors \\
\hline Candace Wells $(\mathrm{CW})^{1 *}$ \\
\hline Author Affiliations \\
\hline${ }^{1}$ Department of Political Science, University of Nevada, Las Vegas, Las Vegas, NV, USA. \\
\hline Corresponding Author \\
\hline *Candace Wells, wellsc6@unlv.nevada.edu \\
\hline Author Contributions \\
\hline $\begin{array}{l}\text { CW: Contributed conceptualization, data collection, literature review, drafting of paper, formal analysis, methodology, } \\
\text { and editing of manuscript. }\end{array}$ \\
\hline Copyright \\
\hline $\begin{array}{l}\text { (C) } \oplus \text { Articles in Spectra are freely available under a Creative Commons Attribution License (CC BY } \\
\frac{4.0) \text { which allows others to re-use the work without permission as long as the work is properly }}{\text { cited. }}\end{array}$ \\
\hline ISSN \\
\hline $2766-7227$ \\
\hline Data Availability Statement \\
\hline The author of this article confirms that all data underlying the findings are fully available without restrictions. \\
\hline Conflicts of Interest \\
\hline The author declares that no conflicts of interest exist. \\
\hline Ethical Considerations \\
\hline $\begin{array}{l}\text { Given that this project did not involve human or animal subjects, no IRB or IACUC approval was needed. All research } \\
\text { was derived from publicly shared sources. }\end{array}$ \\
\hline Funding \\
\hline No funding was provided for this research. \\
\hline Recommended Citation \\
\hline $\begin{array}{l}\text { Wells, C. (2022). The gender wage gap as it relates to state partisan control and pay equity policy. Spectra } \\
\text { Undergraduate Research Journal, 2(1), 14-27. https://doi.org/10.9741/2766-7227.1013 }\end{array}$ \\
\hline
\end{tabular}




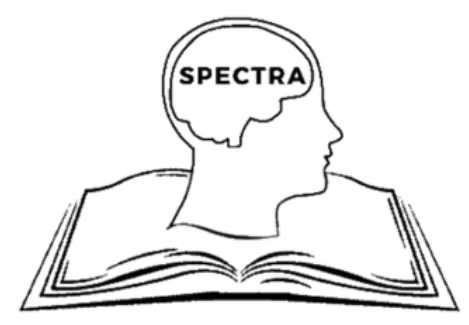

Spectra Undergraduate Research Journal

Volume 2, Issue 1

Office of Undergraduate Research

University of Nevada, Las Vegas

digitalscholarship.unlv.edu/spectra/

\title{
The Gender Wage Gap as it Relates to State Partisan Control and Pay Equity Policy
}

Candace Wells ${ }^{1}$

\section{Author Affiliations:}

${ }^{1}$ Department of Political Science, University of Nevada, Las Vegas, Las Vegas, NV, USA.

\begin{abstract}
This study offers an explanation to the interstate variation of the gender wage gap in the United States. Looking at political explanations as an answer for the wage gap's persistence, I hypothesize that Democratically controlled state government positively impacts the state having pay equity policies, and that having these pay equity policies positively impacts the state's gender wage gap. Using U.S. Census Bureau, National Conference of State Legislatures, and American Association of University Women with U.S. Department of Labor Women's Bureau data, I find that while there is a correlation between Democratically controlled state legislatures and pay equity policy and a correlation between Democratic majority legislatures and a narrower gender wage gap, there does not appear to be a direct association between pay equity policy and the state's gender wage gap. The findings suggest that partisanship of the state legislature plays a key role in the wage equity policy of a state, as well as the reasoning that longstanding Democratic majorities have already passed policy to combat the apparent causes of the gap, and that more in depth policy is thus necessary to completely close it.
\end{abstract}

Keywords: Gender wage gap, state partisanship, pay equity policy

The gender wage gap is a persistent problem in the United States workforce, where women are not fairly compensated for their work. Women being paid less than male counterparts for comparable work discriminates against women nationwide and across industries. Research indicates that on average, women only made about $70 \%$ of what men did for the years 2015-2019. There is variation between each state in the magnitude of their gender pay gaps. In some states, women are paid $10 \%$ less than men, yet in other states, women see as much as a $30 \%$ difference. While reasons for the wage gap have been posed for decades, these explanations have become obsolete with women's educational advancements and professional development over the last 50 years. Though current scholarship has attempted to explain the persistence of the gap, it does not adequately explain the gap's inconsistency across the United States. Acknowledging this gap in the literature, I address whether state pay equity policy implementation is contingent on partisan control of the state legislature and governor's office. Further, I address interstate variation in the gender pay gap as a result of the strength of pay equity policy in each state. A study into the degree to which state government partisanship impacts their pay equity legislation and how this affects the state's gender pay gap will yield results for improvement of state and federal policy on equal pay for women.

The wage gap began narrowing in the 1960s with two legislative efforts, the Equal Pay Act of 1963 and Title VII of the Civil Rights Act of 1964. The Equal Pay Act of 1963 prohibits sex-based wage discrimination between men and women working 
under similar conditions with equal skill. Title VII also prohibits discrimination based on sex, and its protections apply regardless of contradicting state level laws (U.S. Equal Employment Opportunity Commission [EEOC], n.d.). Even with these protections in place, however, the gender wage gap is not currently on track to completely close until 2093 (AAUW, 2020b). A stalling of closing the gap began under Republican presidents Ronald Reagan and his successor George H.W. Bush (Hartmann \& Aaronson, 1994). Both the federal government and courts under these conservative presidents displayed a lack of urgency to recognize and combat the disparity of pay between men and women (Hartmann \& Aaronson, 1994). Since the 1990s, insufficient federal legislation has been passed to close the gap. In response, states have taken it upon themselves to implement their own policies, creating inconsistency in that some states have notably greater or lesser wage gaps.

The circumstances surrounding the gap lead me to pose the question, What are the political causes of wage gap persistence in the United States? Over the course of this project, I address this question by leveraging variation in the states. I pose two testable hypotheses regarding the linkage between partisan control of government and wage equity policy and the adoption of wage equity policies and a decline in the wage gap. While previous scholarship shows a linkage between partisan control in state governments and state policy, and there is some evidence of a linkage between policy and the wage gap, these have not been considered together in a single study. My original contribution to the literature is the full linkage of these phenomena together. Beyond being able to identify whether partisan control matters, I demonstrate how much it matters by quantifying these effects. First, I hypothesize that states with Republican controlled state governments will be less likely to have pay equity laws in place than states with Democratic control. Second, I hypothesize that states with less pay equity policy in place will have a wider wage gap. I seek to determine whether Republican and Democratic control of state governments has a measurable impact on gender wage gaps in terms of pay equity policy enacted.

\section{Literature Review}

Current Policy: Policy that addresses the problem of the wage gap in the United States exists in various strengths across the different levels of government. Pay equity policies are legislative efforts that aim to reduce the gap between the amounts that men and women are paid. This is a broad term, as a variety of public policies can address the gender wage gap (Reese \& Warner, 2012). These policies can be expanded on to include comparable worth (pay equity), unionization, and pay secrecy laws (Kim, 2013). Federally, the Equal Pay Act of 1963 mandates equal pay for equal work. At this time of this law's passage, women made about 59 cents to a man's dollar (Fugiero, 2021). Today, despite this law being enacted for decades, women are still struggling nationwide to be able to make as much as their male counterparts. There is currently no state where the wage gap is not present. Findings by Reese and Warner (2012) suggest that, given a lack of progress in pay equity policy, the wage gap will not improve without federal or state intervention. They look at pay equity implementation at the state level to determine if successful national policy is feasible. Their analysis of state level pay equity efforts, in lieu of more federal legislation, demonstrates that states can successfully prevent gender wage discrimination. Without more national intervention, or all 50 states adopting pay equity legislation, the wage gap will remain stagnant. Kulow (2013) notes that illegal wage discrimination, which perpetuates the wage gap, persists today due to inadequate laws and protections. In the absence of stronger federal advancement towards narrowing the gap, some states have taken it upon themselves to further address the issue, while others have not.

Figure 1 visually displays the contrast across the United States in terms of women's earnings compared to men's. This map, by the AAUW (2021), uses 2019 median annual earnings to demonstrate that certain states have significantly wider gaps than others. While some states have pay ratios as low as 70\%, 90\% is the highest amount to which women are paid relative to men's earnings. Women earning $90 \%$ of what men earn is not ideal, but most states struggle to even meet this threshold. Women in certain states earning only $70 \%$ of what men do decades after the Equal Pay Act highlights that some states are more proactive than others in enforcing equal pay laws between men and 
women. This proactivity may be found in the form of emphasized state policy regarding pay equity.

\section{Figure 1.}

Map of the gender wage gap by state 2019
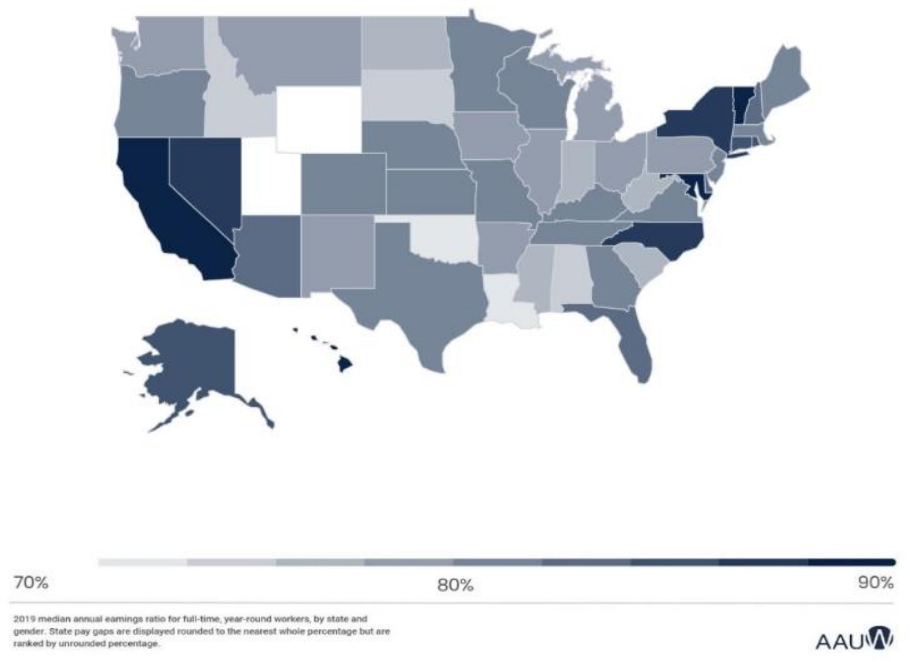

According to the AAUW, the nine states with the most protection against gender based pay discrimination are California, Colorado, Illinois, Maryland, Massachusetts, New Jersey, New York, Oregon, and Washington (2021). The association categorizes this strength based on the protections in place, with policy components such as prohibiting retaliation and discrimination for taking legal action to secure equal pay and using salary history in hiring. The remaining 41 states hover between moderate, weak, and no protection. The only state with no protections beyond the Equal Pay Act of 1963 is Mississippi (AAUW, 2021). Census (2019a) data indicates that between 2015 and 2019, women in Mississippi made only 70 cents to a man's dollar. These data highlight the stark variation among the states in terms of the number of pay equity policies, or lack thereof, enacted within the state.

Kim (2013) asserts that no singular policy can completely close the gap. However, pay equity policies often face difficulty being introduced, let alone implemented, federally due to controversy and disagreement raised by both economists and lawmakers. The Paycheck Fairness Act, which strengthens Title VII against loopholes, has been presented in Congress over 20 times without being passed. To make significant progress and get around federal gridlock, Kim (2013) urges for a more strategic state based approach instead. At the state level, policies to end the gender gap have a greater chance for success.

Some states have already implemented this approach. Hartmann and Aaronson (1994) exemplify the possibility for success via their analysis of 16 out of 20 states who had engaged in pay equity implementation by 1989 . The states included in the analysis are California, Connecticut, Florida, Hawaii, Illinois, Iowa, Maine, Massachusetts, Michigan, Minnesota, New Jersey, New Mexico, New York, Oregon, Pennsylvania, Rhode Island, South Dakota, Vermont, Washington, and Wisconsin. The 16 studied states' strategies either targeted adjustment of traditionally undervalued and female jobs or large changes to personnel systems. Hartmann and Aaronson (1994) note that the types of programs implemented by each state depended on the state's starting place relative to equal pay for women. They find that, generally, the states that invested the most in pay equity implementation saw the most progress in narrowing their gender pay gap.

Targeting also appears to be the more efficient and effective method of attacking pay disparities. The pay equity legislation did not have the negative secondary effects such as employment loss (Hartmann \& Aaronson, 1994). Ultimately, the findings of this study show that successful pay equity is both doable for all states, without job loss. By accounting for states at different levels of pay equity to begin with, the study demonstrates that a full scale launch of strengthening pay equity legislation in all states would be both possible and beneficial. Showcasing the success of each of the two strategies, targeted and systemic, other states can evaluate which strategy would work best for them. Increased pay equity legislation, especially in states with currently minimal protections, would make a positive impact on the wages of women nationwide.

Other scholars echo these sentiments. Reese and Warner (2012) analyze gender-based pay adjustments' impacts over 25 years by looking at the effects of pay equity for a longer time period than Hartmann and Aaronson (1994). They find a significant difference in relative pay of women in states that have enacted pay equity policies and programs. It is worth noting that five of the AAUW's strongest ranked states are among those who had implemented 
pay equity policy by 1989 in Hartmann and Aaronson's (1994) study. Research indicates that there is more pay equity benefit for women in states that have enacted pay equity policy. Ultimately, pay equity policies, when implemented, are effective in diminishing the wage gap.

The stagnation of progress in closing the gap that has arisen since the 1990s is called wage inertia. This term accounts for the slowdown in gap narrowing measures that has impacted women of all races and earning groups (Billitteri, 2008). This inertia particularly affects the non-merit-based portion of the gap, or the discriminatory components of the gap (Mandel \& Semyonov, 2014). Some economists criticize equity efforts as unnecessary, arguing the stagnation is a result of women's actions rather than systemic discrimination. Specifically, economists cite the difference in pay between men and women as resulting from individualistic or merit based factors. Hartmann and Aaronson (1994) note that economists see pay equity implementation as potentially derailing the status quo of the labor market. Lawmakers echo economists' contentions that the wage gap is attributable to individualistic factors and therefore additional policies are unnecessary (Misra \& MurrayClose, 2014). Some elected officials have gone so far as to undo the pay equity progress made in their state. In Wisconsin, former Republican governor Scott Walker repealed the state's Equal Pay Enforcement Act in 2012. Similarly, former Republican governor of Texas Rick Perry vetoed the 2013 Texas Equal Pay Bill (Misra \& Murray-Close, 2014). By slowing down or stopping pay equity efforts in their states, both of these governors convey that wage equity policy is not necessary.

Currently, the U.S. economy faces a myriad of problems, including labor shortages, a pandemic induced recession, and rising inflation rates. Inadequate pay equity policy poses a large threat to stability and growth for the United States economy, women, and their families.

Continuing to neglect addressing and resolving the issue of the gender wage gap hinders the war on poverty. The poverty rate among working women could be halved if women were paid the same as male counterparts. Additionally, equal pay would add $\$ 512.6$ billion to the U.S. economy in income, nearly three percent of 2016's GDP (Milli et al., 2017). While many women take a break from the workforce to focus on motherhood, almost 26 million children would benefit from their mothers being paid fairly, and the poverty rate among working single mothers would halve (Milli et al., 2017). It is imperative to the future and success of the nation to address the issue of women being unfairly underpaid.

Merit Based and Non-Merit Based Portions of the Gap: The causes of the wage gap can be separated into two categories. Mandel and Semyonov (2014) characterize these two categories as the "explained and unexplained" portions of the gap, which are merit based components, such as human capital factors and work related characteristics, and unobserved, nonmerit based components. Controlling for merit-based components, Mandel and Semyonov (2014) argue that what remains are discriminatory components of the gender wage gap based on unobserved predictors. Kulow (2013) argues that the "merit gap," including education level, experience, seniority level, and occupational segregation is mostly closed. The merit based portion of the gap has become an obsolete explanation for the gap's persistence and does not completely account for the wage gap (Kulow, 2013). The differences between men and women in terms of labor market skills have diminished over the past decades, leaving a portion of the wage gap unaccounted for (Kulow, 2013; Misra \& MurrayClose, 2014). Women have greatly increased their work experience, and outpaced men in higher educational attainment (Mandel \& Semyonov, 2014). As of 2017, the number of women with master's and bachelor's degrees outnumbers that of men (AAUW, 2020a). Additionally, England (2006) finds occupational based segregation, or the sorting of women into "female" typed, and historically underpaid, positions declined between 1960 and 2000. This decline was most noticeable among the highly educated, reflecting women beginning to match qualifications of men breaking into male dominated occupations. Remaining occupational segregation, paired with traditionally female jobs having lower wages, perpetuates the wage gap (Goldin, 1990). Ultimately, when human capital factors are considered, $41 \%$ of the gap remains that cannot be explained by differences in merit (Blau \& Kahn, 2007). Despite comparable characteristics and traits between men and 
women in the Twenty-first century, women are still paid less.

Altogether, the merit based portion accounts for economists and lawmakers' qualms about the necessity of pay equity legislation. Research shows that the nonmerit based portion of the gap is perpetuated by discriminatory factors outside the control of individuals, and therefore requires the intervention of the government in the form of increased policy.

Political Explanations: Partisan control of state government does affect the state's policy; specifically, Democratic elected officials lead to more liberal policies (Caughey et al., 2017). Kuk and Hajnal (2021) examine this phenomenon, assessing whether partisan control affects gender inequality. They look to see if Democratic control of the state legislature and governor's office leads to a decline in gender inequality. While the topic of gender inequality includes the gender wage gap, their study is not focused solely on earning disparities between men and women. Their findings show that electing more Democrats and women leads to increasingly liberal policy on gender inequity (Kuk \& Hajnal, 2021). They also find women experience more economic gains in relation to men under Democratic control than Republican control (Kuk \& Hajnal, 2021). These economic gains include narrowing the wage gap and a decline in female unemployment.

Two causal mechanisms are identified in Kuk and Hajnal's (2021) study between partisan state control and gender inequality: policies related to gender and female representation. The gender policy they focus on regards abortions and women's rights, which are outside the scope of what I aim to look at. While women's rights can include being paid equally to men, this topic inherently includes a wide array of issues such as abortion and healthcare policy, domestic violence policy, and others that do not pertain to the gender wage gap. The data demonstrates partisan control can impact gender related policies; however, this impact also applies to more than just income inequality between men and women. Therefore, I find it crucial to build on Kuk and Hajnal's study by looking at gender policy specifically regarding pay equity. Addressing the effect of partisan control of state government on this policy, I aim to link it to pay equity policy's impact on the gender wage gap. An additional original contribution that builds on this study is my use of more recent data.

Female Politicians: Female politicians play an important role in the passage of pay equity policy. Kuk and Hajnal (2021) identify women as an essential component of partisanship's effect on gender inequality. Thomsen (2015) notes current patterns of women's representation are starkly Democratic. Democratic women are consistently more liberal than Democratic men, leading to more liberal policies and higher likelihood of passing pay equity legislation (Osborn et al., 2019; Reese \& Warner, 2012). Given pay equity policy is a progressive policy, these findings suggest that Democratic women have positive impacts on pay equity policy. While my study does not examine female politicians as a causal mechanism, their rising numbers and priorities have a clear importance to policy agenda that requires an in depth look at their role in pay equity policy.

Women are being elected to office at higher rates than ever before, yet they continue to be greatly underrepresented in Congress (Sanbonmatsu, 2020). This suggests that women's issues are underrepresented at the federal level as well. Volden, Wiseman, and Wittmer (2018) identify women's issues as concerns that women are more likely to raise or raise at a greater volume. Pay equity policy can be classified as a woman's issue from the consistent and numerous introductions by women of the Paycheck Fairness Act into Congress. This policy seeks to diminish wage inequality by holding employers to more rigid standards and requiring more transparency in wage justifications. Democratic women in both houses have proposed the bill during every congressional session over the past decade. Despite the congresswomens' persistence, the bill has yet to successfully pass both houses. The resistance to the Paycheck Fairness Act is consistent with treatment of other bills sponsored by women in Congress, given bills sponsored by women are systematically more gridlocked than bills sponsored by men (Volden et al., 2018). Volden, Wiseman, and Wittmer $(2018,721)$ also find that congresswomen's legislative proposals, especially ones regarding women's issues, are "systematically dismissed and disregarded throughout the legislative process, relative to those of men." Given the underrepresentation that women and their issues face, policy to help correct the gender wage gap meets 
significant challenges (Burrell, 1994). Under these conditions, it becomes clear why more federal policy regarding the wage gap has not been enacted. The arduous battle women's issues face at the federal level may be better remedied by female politicians at the state level. However, these findings may also demonstrate why some states have been able to pass significant pay equity policy and others have not. If the conditions of congresswomen are replicated for women in the state legislature, it may serve to explain the gap's persistence and absence of sufficient policy to close it.

State level politicians who can impact wage equity policy in their states include the governor and state legislature. Nationwide, both of these branches are overwhelmingly held by men, but women in these roles can disrupt the status quo by increasing the amount of representation women's issues receive. While Volden et al. (2018) do not see women impacting policy passage federally, Reese and Warner (2012) find that gender composition of state government is an important indicator of the types of policies it enacts. Reese and Warner (2012) expect states with higher percentages of female legislators or female governors to have a narrower wage gap than states with smaller percentages of female legislators or male governors. Research suggests that women in state legislature persist in being more liberal in their policy agenda (Whistler \& Ellickson, 1999). This liberalism by female legislators can be translated to a prioritization of women's issues. Reese and Warner (2012) also find that women are successful in introduction and passage of more liberal policies, including pay equity. Pay equity policy thus finds greater popularity and success among liberal and female politicians.

Female politicians occupy a distinct role in legislation, despite smaller membership among legislatures. Whistler and Ellickson (1999) find that female legislators are more likely to initiate legislation than male legislators. This legislation focuses on women's issues at a higher rate than men's initiated legislation. Bratton (2005) demonstrates that even where they make up less than $15 \%$ of the legislature, women are generally more active than men in sponsoring legislation that focuses on women's interests. Female legislators are also more likely to specialize in legislation than men, and this specialization is often in women's issues policy. (Whistler \& Ellickson, 1999; Volden et al., 2018). These findings all suggest that women are a key component of legislation, specifically policy regarding women's issues and the gender wage gap. However, the findings also suggest that their presence in state government impacts the legislative agenda, perhaps not the passage of legislation.

Religiosity: Women joining the workforce and prioritizing their careers distances them from the more traditional role of homemaker that many religions emphasize. Research suggests that stronger religious beliefs and more religious participation are associated with a larger wage gap at the state level (Wiseman \& Dutta, 2016). Sitzmann and Campbell (2020) also find that religiosity widens the gender wage gap. Looking at the predictive power of religiosity on all 50 United States, they find that the gap is narrowing significantly faster in more secular states (Sitzmann \& Campbell, 2020). This may be due to religion's impact on wage equity policy, given religion effects on public policy outcomes (Castles, 1994). Castles (1994) finds that religion matters in regard to gender-related issues and the rights of women, considering Christianity's historical emphasis on these issues. Pew's (2020) Religious Landscape Study shows $70 \%$ of religious people in the U.S. are of Christian faith, and the two largest denominations of Christianity in the U.S. are Catholicism and Protestantism. Both Protestants and Catholics have been historically and fundamentally opposed to acts interpreted as destructive of family life, such as women focusing on a career (Castles, 1994). Beyond this, research by Sitzmann and Campbell (2020) demonstrates religiosity's effect on the gender wage gap applies to the major world religions in addition to Christianity. Overall, research indicates that religion does have some negative impacts on the gender wage gaps in states.

Theory: This paper focuses on the effects of partisan control of the state legislature and governor's office on pay equity policy of a state, and that policy's effect on the state's gender wage gap. I seek to establish a causal chain between partisan control, pay equity policy, and the gender wage gap.

Kuk and Hajnal (2021) demonstrated Democratic control of the state government has substantial effects on gender-related policy. I expect this finding to apply to pay equity policy, with women 
seeing more pay equity policy passed under Democratic control than Republican. The wage inertia of the last 30 years coincides with dramatic growth of partisan effect on state policies, with polarization having increasing importance in policy passage (Caughey et al., 2017; Kuk \& Hajnal, 2021). Such pronounced and divided partisanship serves to explain the interstate variation in both passage of pay equity policy and the wage gap. Additionally, Caughey et al., (2017) find the election of state level Democrats has produced an increasing divergence in policies implemented, with Democrats positively impacting policy liberalism. Given pay equity policy being classified as liberal policy, these findings support pay equity policy passing at a higher and stronger rate in Democratic controlled states. The passage of liberal policy that benefits women being tied not only to the election of Democrats, but also the election of women, draws attention to the higher percentage of Democratic females elected than the Republican (Kuk \& Hajnal, 2021; Thomsen, 2015). The partisan control of states results in certain policy priorities, which see pay equity emphasized or deemphasized. Parties' prioritization, or lack thereof, of pay equity policies has consequences for the wage gap, leading to its narrowing or continuation.

The passage of pay equity policy in a state should serve to narrow the wage gap of the state. Democrats' passage of more liberal, female benefitting policy leads to a declination in gender inequality, including that of income and wages (Kuk \& Hajnal, 2021). As more legislation passes in a state, protection for women against non-merit based portions of the gap, or various forms of discrimination increases substantially (Mandel \& Semyonov, 2014). Pay equity laws focus on areas such as equal pay and comparable worth, mandatory wage disclosure, and prohibition of employer retaliation and discrimination for discussion of wages. These policy efforts target the wage gap and demonstrate efforts to lessen the difference between men and women's pay. I expect states which have made stronger efforts via policy passage to have a narrower wage gap.

The apparent association between partisan control of state governments and gender wage gaps in terms of pay equity policy enacted prompts me to examine their relationship. To accurately address my research question of "What are the political causes of wage gap persistence in the United States?" I pose two hypotheses:

Hypothesis I: In a comparison of states, those with Republican controlled state legislatures and governor's office will be less likely to have pay equity laws in place than will those having Democratic controlled state legislatures and governor's office.

Hypothesis II: In a comparison of states, those without pay equity laws in place will be more likely to have higher gender pay gaps than will those having more pay equity legislation.

\section{Data}

The data used in this study, including case selection, best reflects the specific hypotheses being posed. Limited availability in terms of data, for both the independent and dependent variables, hinders the ability to address certain questions, spanning beyond the scope of this study. The data used attempts to explain partisanship's impact on the gender wage gap via policy implementation for the years of data available.

The independent variable of Hypothesis I is the partisanship of the state legislature and governor's office for a given year. To determine the partisanship of state level governments, I use the National Conference of State Legislatures' (NCSL) Legislative Partisan Composition Table for data on partisan control of state legislature and governor's office for the years 2015 and 2019 (Williams \& Mahoney, 2021). They determine partisan control with the following conditions: When the same party holds both chambers, that party has legislative control. When the chambers are held by different parties, it is divided. When the same party holds both legislative chambers and the governor's office, that party has state control. When any of those three points of power is held by another party, state control is considered divided. This is based on the number of members of each party and does not take into account coalitions that might change effective control. Nebraska is not included in the state legislature partisanship data because it has a unicameral, nonpartisan government. The NCSL's formula for determining state partisan control relies on using partisanship of the state legislature, which Nebraska does not have, so it is excluded from this account as well. Therefore, the state of Nebraska is not included in my dataset. 
The dependent variable of Hypothesis I and the independent variable of Hypothesis II is pay equity policy, which is defined as legislative efforts that aim to reduce the gap between the amounts that men and women are paid, including comparable worth (pay equity) and pay secrecy and transparency. The AAUW's Policy Guide to Equal Pay charts the strength of each state in terms of equal pay laws by identifying key categories of pay equity policy. These categories include protections, occupational segregation, defense, remedies, procedures, and preventative measures. Laws to combat against employer retaliation for employees taking legal action, requiring employers to pay the employee's legal fees, and requiring employers to keep records of wages are examples of the types of laws that help characterize a state as stronger or weaker in terms of pay equity policy. Additionally, each policy is documented by the U.S. Department of Labor Women's Bureau (U.S. Department of Labor Women's Bureau, n.d.). Their webpage "Equal Pay and Pay Transparency Protections" provides detailed information of the wage gap policy protections for women in each state, including the codes and names of the laws. All 49 states in my study were evaluated on a 13 measure pay equity policy scale and then given a policy score out of 13 , with a higher score reflecting more policy in place and a lower score reflecting less policy. Given the AAUW includes data from 2015 up to 2019, each states' policy score is treated as a constant variable in the analysis.

The dependent variable for Hypothesis II is the gender wage gap. This gap is the difference between men and women's salaries, expressed as the percentage of men's salaries that women make annually. For the gender wage gap data by state, I look at the table "Occupation by Sex and Median Earnings in the Past 12 months" from the U.S. Census Bureau American Community Survey for the years of 2015 and 2019. The data table includes the median annual salary of both men and women by state for all 50 states. It also expresses women's earnings as a percentage of men, displaying each state's gender pay gap. This percentage is calculated by taking the women's median earnings and dividing it by the men's median earnings for each state.

The unit of analysis in my study is a state for the years 2015 and 2019. These years reflect the available data for a majority of my data sources, including the Census tables regarding the gender wage gap by state, racial breakdown by state, and the NCSL data available on partisanship of state legislatures as well as percentage of female legislators. Though it is not a long time period, it is still beneficial to evaluate the effect of partisanship on wage equity policy utilizing such recent data. Looking at states in both 2015 and 2019, I am able to understand the wage gap over time and see the progress, or regression, of the states in terms of their individual wage gaps. Additionally, given Nebraska's unicameral legislature, the number of states I examine is 49 as opposed to 50 . None of my statistical analysis includes Nebraska.

A state's gross domestic product is a measure of the strength of the economy, based on the monetary value of the goods and services of a state in a certain time period, which in my study is the years 2015 and 2019. I utilize the Bureau of Economic Analysis' real GDP in millions of chained 2012 dollars for each state for the years of 2015 and 2019. Census (2019a) demonstrates a varying gender wage gap by state by industry and occupation, with variation that should prompt consideration of the state's GDP.

Given the unique influence on policy agenda women demonstrate regarding women's issues, including pay equity, I control for the percentage of female legislators in a state's legislature. I utilize the NCSL's "Women in the State Legislatures" dataset from the years 2015 and 2019 to account for the percentage of women in each state's legislature. NCSL has compiled annually the number of female legislators in each state and computed the percentage of women in the legislature per state. Using their data on the number of women in the state legislature, I am able to control for female legislators' influence on their state's policy.

State religiosity refers to how religious the population of a state is. Research shows religion has negative impacts on the narrowing of the gender wage gap by state, therefore I control for it using Pew Research Center data. The dataset "How Religious is Your State?" measures states' religiosity by ranking each state based on citizen responses to a four pronged feeling thermometer on religion (Pew Research Center, 2020). The ranking displays the percentages of citizens of a state who say religion is very important in their lives, say they attend worship services at least weekly, say they pray daily, say they believe in God with 
absolute certainty. This percentage is the population of "highly religious" citizens of that state.

Intersectionality among female workers is important to consider given that the severity of the gender gap varies depending on race and ethnicity of women (AAUW, 2020b). States with greater workforce populations of non-white females may therefore have larger wage gaps. While ideally, I would use wage gap data by race by state to assess the intersectionality of the gender based pay gap, limitations on the availability of this data require generalization. I compensate for the unavailable data by interacting a variable that measures racial variation for each state with each state's policy score as a proxy. The data comes from Census Bureau American Community Survey 2019 tables for total population by state for each major race in the United States, which includes white, black, Asian, Native American (American Indian) and Alaska Native. The ethnicities of Hispanic or Latino are taken from total population by state from the 2020 decennial Census program.

\section{Analyses}

Hypothesis I expects to see the composition of the state government influence the amount of pay equity laws in place in the state. Specifically, Republican controlled state governments will have less pay equity policy in place, where Democratic controlled state governments have more. Hypothesis II expects the states with more pay equity policy in place to have narrower wage gaps.

\section{Table 1}

\section{Descriptive statistics}

\begin{tabular}{lllll} 
Variable & Mean & Std. Dev. & Min & Max \\
\hline WageGap_19 & 72.224 & 5.07 & 58.3 & 82.1 \\
PolicySco 19 & 6.899 & 2.917 & 0 & 11 \\
control_15 & -0.327 & 0.718 & -1 & 1 \\
DemLeg15 & 0.224 & 0.422 & 0 & 1 \\
DemGov15 & 0.367 & 0.487 & 0 & 1 \\
DemLeg19 & 0.367 & 0.487 & 0 & 1 \\
DemGov19 & 0.469 & 0.504 & 0 & 1 \\
PctWomenL 15 & 24.418 & 7.123 & 11.8 & 43 \\
PctHighly 15 & 54.714 & 10.853 & 33 & 77 \\
RealGross 19 & 381366.6 & 495757.9 & 29806.2 & 2800595 \\
nonwhite1 00 & 25.06 & 12.9111 & 4.539 & 65.041
\end{tabular}

$\mathrm{N}$ of 49 for all observations.
I test the two hypotheses by running OLS regression models to predict pay equity laws (Hypothesis I) and gender wage gap (Hypothesis II) as a function of the independent variables. For the first model, the dependent variable, pay equity policy, shows a correlation with Democratic legislature in 2015. The independent effect of the Democratically controlled legislature shows an increase of 2.8 on the policy score in 2015. This is holding constant the proportion of women in the legislature, the proportion of the population that is highly religious, and the partisanship of the governor's office. In the second model, the dependent variable, wage gap of the state, does not appear to be associated with the independent variable of Democratically controlled government, indicating that there is no direct correlation between the wage gap and wage gap policy. Neither of the variables being used to predict the wage gap, being state policy score and GDP, appear to have an association with the wage gap of the state. Hypothesis II, therefore, does not hold up against statistical testing. I do not see the stepwise effect posed by my hypotheses of Democratic control to policy and that policy to wage gap, most likely due to the timeframe of my study.

However, when the political controls are added of Democratic legislature and governor's office, there does appear to be a relationship between Democratic legislature and the wage gap. Specifically, Democratic legislative control is positively associated with wage equity. This cross-sectional model utilizes political control variables for 2019 to reflect more current data, and indicates that Democratic legislators affect policy, and most likely have been for a long time. Controlling for strength of pay equity policy, GDP, and Democratic legislative control, strength of policy is not associated with the wage gap, but Democratic legislature is. These results observationally suggest that Democratic control of the legislature is correlated with higher levels of wage equity policy and with greater wage equity. This may be a function of the time period of 2015 and 2019. It is possible that, having a majority for a long time, the Democratic legislature of a state has already done the work of reducing the wage gap. This gives the perception that the policies that these legislators have in place are not correlated with a lower wage gap. 


\section{Results}

For Hypothesis I, which examines the relationship between partisan control of the state government and pay equity policy in a state, Table 2 demonstrates a fairly strong positive association between partisan control of a state and the pay equity policy in the state. Government control of the state is coded -1 for Republican, 0 for split, and 1 for Democratic. As the partisan control of the state government moves one unit, from either Republican to split or split to Democratic control, there is a change of 1.87. Democratic partisan control, therefore, appears to be predictive of pay equity policy in a state. Partisan control of the governor's office, however, does not appear to be associated with the passage of wage equity policy. Additionally, the percentage of women in the legislature of the state and percent of the state that is highly religious do not appear to be associated with wage equity policy either. The percentage of women in the legislature not being associated reflects some previous scholarships' findings that women are influential in the legislative agenda, rather than legislative passing. Looking more closely at partisan control, the third model looks at Democratic legislative control versus Democratic governor's mansion, holding all other factors included in the model constant. Here, the data shows that the legislature specifically, not the governor's mansion, is what impacts pay equity policy.

Table 2

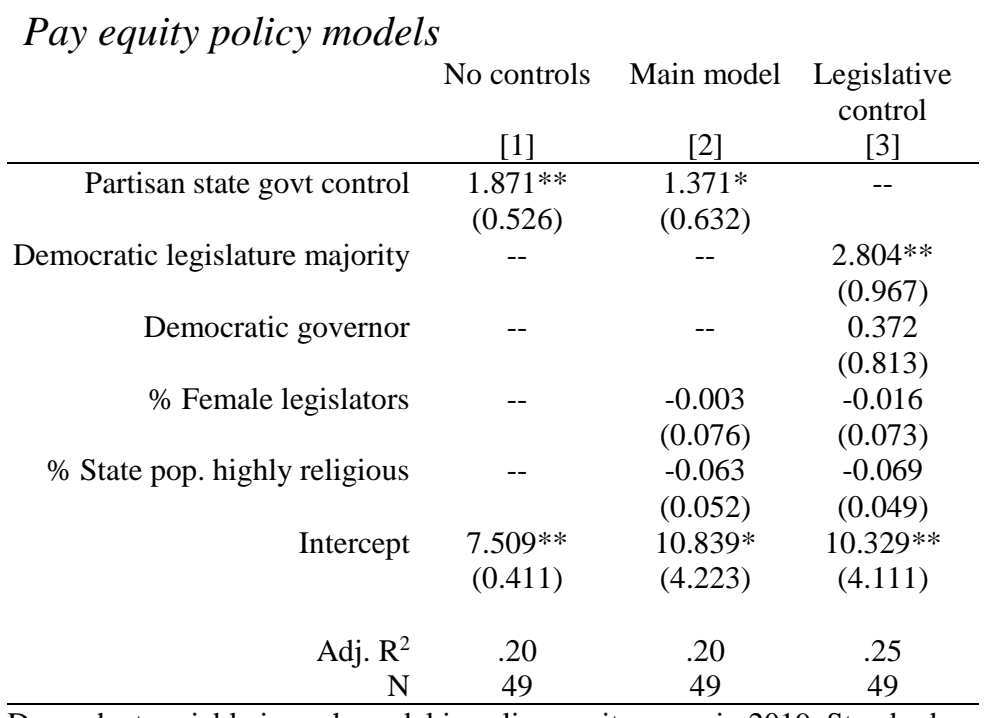

Dependent variable in each model is policy equity score in 2019. Standard errors in parentheses below OLS coefficients. ${ }^{*} p<.05$, $* * p<.01$, two-tailed tests
Table 3 looks at the wage gap cross-sectionally, in 2019. The data looks at the current policy in place and controls for the size of the economy in predicting the wage gap. For Hypothesis II, which addresses how wage equity policy is predictive of the wage equity in a state, I find that it is not predictive. The table shows that there are no significant effects, the current policy is unrelated to the current state of the wage gap. Given the null results, it is unexpected that the racial composition of the workforce would be significant, but it is possible for an effect to be disguised by a highly positive effect for the white population and a highly negative effect for non-whites cancelling out. To account for this, the table shows the interaction between policy and non-white population. The data does not indicate that there is an effect. Interestingly, there was also no effect of policy on the wage gap. However, when partisan control was added, Democratic legislature presents again as a significant predictor of the wage gap. This suggests that perhaps the policy score used in this study is not an accurate measure of the policy in the state. Alternatively, while wage equity policy and the wage gap do not appear to be associated, there is reason to believe that it is not associated in this case because many of the policies that create the pay equity policy score could have been adopted long before 2015. Therefore, I am observing the end of the process. Additionally, another condition that could produce this distribution is the possibility that some states have only recently adopted wage equity policy and have a larger wage gap, where other states adopted wage equity policy a long time ago and have smaller wage gaps. These circumstances would demonstrate in the model that the variables are not correlated. This would be a result of the limitations on my available data, which do not allow me to see a linkage on slowly evolving policy such as pay equity policy. 
Table 3

\section{Wage gap models}

\begin{tabular}{|c|c|c|c|}
\hline & $\begin{array}{c}\text { Base } \\
\text { model } \\
{[1]}\end{array}$ & $\begin{array}{c}\text { Racial Bias } \\
{[2]} \\
\end{array}$ & $\begin{array}{c}\text { Democratic } \\
\text { control } \\
{[3]}\end{array}$ \\
\hline Pay equity & 0.070 & 0.756 & -0.266 \\
\hline & $(0.253)$ & $(0.714)$ & $(0.280)$ \\
\hline $\begin{array}{r}\text { Pay equity } \\
\text { policy } x\end{array}$ & -- & -0.021 & -- \\
\hline $\begin{array}{l}\% \text { non-white } \\
\text { population }\end{array}$ & & $(0.023)$ & \\
\hline State GDP & $<-0.001$ & $<-0.001$ & $<-0.001$ \\
\hline & $(<0.001)$ & $(<0.001)$ & $(<0.001)$ \\
\hline $\begin{array}{r}\text { Democratic } \\
\text { legislature } \\
\text { majority }\end{array}$ & -- & 4.034 & $4.872 *$ \\
\hline & & (1.867) & (1.846) \\
\hline $\begin{array}{r}\% \text { non-white } \\
\text { population }\end{array}$ & -- & $\begin{array}{l}0.280 \\
(0.176)\end{array}$ & -- \\
\hline $\begin{array}{r}\text { Democratic } \\
\text { governor }\end{array}$ & -- & -2.413 & -2.116 \\
\hline Intercept & 71.022 & 63.279 & 72.586 \\
\hline & (1.916) & $(5.479)$ & (1.916) \\
\hline $\operatorname{Adj} . R^{2}$ & $<.01$ & .07 & .14 \\
\hline$N$ & 49 & 49 & 49 \\
\hline
\end{tabular}

Dependent variable in each model is gender wage gap in 2019. Standard errors in parentheses below OLS coefficients. ${ }^{*} \mathrm{p}<.05, * * \mathrm{p}<.01$, two-tailed tests

\section{Conclusion}

This study has addressed an explanation for political causes of gender wage gap persistence in the United States. Looking at the effects of state partisanship on state pay equity policy and pay equity policy's effect on the state's gender wage gap, I have sought to answer the question of why there is interstate variation in the gender wage gap. The results of my study indicate that certain political offices exude influence over the passage of pay equity policy, and that this policy does not inherently appear to affect the wage gap.

The findings of Hypothesis I are consistent with partisan results demonstrated by previous scholars. As expected, a Democratically controlled state legislature does have a positive impact on a state's wage equity policy. Interestingly, however, the governor's office does not appear to have an effect on it. This may be due to the role of the governor in terms of policy passage. The governor occupies the executive role of the state, which involves signing off on policy that has passed in the legislature. The state legislature is tasked with creating and passing bills, which involves legislators more deeply in the issue of pay equity policy, having to either defend or attack it. Also interesting is the finding that the percentage of women in the legislature does not impact the passage of pay equity policy. This finding may be a result of the short timeframe of the study, as it is possible that most pay equity policy in the states was passed before 2015 . The lack of association between the percent of the state that is highly religious and the passage of pay equity policy calls into question previous research asserting religion's negative impact on the wage gap. However, religion may simply negatively affect a state's wage gap outside of the scope of policy, in other forms unaccounted for in this study.

The findings of Hypothesis II with the addition of political controls suggest the existence of Democratic control over a state's legislature, prior to the years studied in this analysis, has already passed the legislation that would show a correlation between it and the wage gap in this study. In other words, that a point may already have been reached regarding the wage gap where existing wage equity laws passed long before 2015 have accomplished the easier goals in terms of reducing the wage gap. As demonstrated by other scholars, the merit-based portion of the gap has closed. Women are up to par with men in terms of academic achievement and work experience attainment. This is likely a reflection of both women's efforts and the implementation of laws to protect women from the more blatant aspects of pay inequity. Now, more difficult feats remain of addressing why the wage gap continues to persist, and what kind of policies it will take to end it.

Alternatively, it is possible that the relationship between the Democratic legislature and the wage gap in my data is spurious, due to an observed variable causing both a Democratic majority and narrower wage gap. In not being able to capture this unobserved variable, my results would display a significant, but spurious, result. The persistence of the non-merit based portion of the gap, perpetuated by discriminatory components, requires more scrutiny of employer practices and more advanced and immersive policy 
strategies of overcoming gender pay discrimination. This paper leaves room for more analysis into the stepwise effects of partisanship on pay equity policy, and that policy's effect on the gender wage gap. Failure to show a linkage between pay equity policy and the gender wage gap is likely a function of the time frame of the data, prompting the use of data that encompasses a larger timespan. The notability of Democratic control of the legislature on pay equity policy highlights partisanship's impact on the fate of a state's policy. There is also room for the analysis of variables not considered in this paper, of which may cause a Democratic legislative majority and narrower wage gap. Future work may continue to explore the relationship between partisanship and pay equity policy in an attempt to better understand the most effective way to diminish interstate variation in the wage gap, with a goal of closing it nationwide.

\section{References}

AAUW. (2020a). Education - AAUW: Empowering Women Since 1881. https://www.aauw.org/issues/education/

AAUW. (2020b). The simple truth about the pay gap. https://www.aauw.org/resources/research/simp le-truth/

AAUW. (2021). Gender pay gap by state - AAUW : Empowering Women Since 1881. https://www.aauw.org/resources/article/gender -pay-gap-by-state/

Billitteri, T. J. (2008). Gender pay gap. $C Q$ Researcher, 18(11), 241-64. http://library.cqpress.com/cqresearcher/cqresrr e2008031400

Bureau of Economic Analysis. (2019). GDP and personal income. https://apps.bea.gov/iTable/index_regional.cf $\mathrm{m}$

Bratton, K. A. (2005). Critical mass theory revisited: The behavior and success of token women in state legislatures. Politics \& Gender, 1(1), 97125

Blau, F., \& Kahn, L.M. (2007). The gender pay gap: Have women gone as far as they can? Academy of Management Perspectives, 21(1), 7-23

Burrell, B. C. (1994). A woman's place is in the House: Campaigning for congress in the feminist era. The University of Michigan Press
Castles, F. G. (1994). On religion and public policy: Does Catholicism make a difference? European Journal of Political Research, 25(1), 19-40. https://doi.org/10.1111/j.14756765.1994.tb01199.x

Caughey, D., Warshaw, C. \& Yiqing, X. (2017). Incremental democracy: The policy effects of partisan control of state government. Journal of Politics, 79, 1-17

England, P. (2006). Toward gender equality: Progress and bottlenecks. The Declining Significance of Gender? (pp. 245-264). Russell Sage Foundation.

Fugiero, M. (2021). Equal pay act of 1963. Encyclopedia Britannica. https://www.britannica.com/topic/Equal-PayAct

Goldin, C. (1990). Understanding the gender gap: An economic history of American women. Oxford University Press

Hartmann, H. I. \& Aaronson, S. (1994). Pay equity and women's wage increases: Success in the states, a model for the nation. Duke Journal of Gender Law \& Policy, 1(69), 69-87

Kim, M. (2013). Policies to end the gender wage gap in the United States. The Review of Radical Political Economics, 45(3), 278-83. https://doi.org/10.1177/0486613413487159

Kuk, J., \& Hajnal, Z. (2021). Democratic party control reduces gender inequality. Legislative Studies Quarterly, 46(1), 155-88. https://doi.org/10.1111/lsq.12316

Kulow, M. D. (2013). Beyond the Paycheck Fairness Act. Harvard Journal on Legislation, 50(2), 385-445

Mandel, H., \& Semyonov, M. (2014). Gender pay gap and employment sector: Sources of earnings disparities in the United States, 1970-2010. Demography, 51(5), 1597-618

Milli, J., Huang, Y., Hartmann, H., \& Hayes, J. (2017). The impact of equal pay on poverty and the economy. Institute for Women's Policy Research. https://iwpr.org/wpcontent/uploads/2020/09/C455.pdf

Misra, J., \& Murray-Close, M. (2014). The gender wage gap in the United States and cross nationally. Sociology Compass, 8, 1281-1295. https://doi: 10.1111/soc4.12213 
National Conference of State Legislatures. (2015). Women in the state legislatures for 2015. https://www.ncsl.org/legislatorsstaff/legislators/womens-legislativenetwork/women-in-state-legislatures-for2015.aspx

National Conference of State Legislatures. (2019). Women in the state legislatures for 2019. https://www.ncsl.org/legislatorsstaff/legislators/womens-legislativenetwork/women-in-state-legislatures-for2019.aspx

Osborn, T., Kreitzer, R. J., Schilling, E., \& Hayes Clark, J. (2019). Ideology and polarization among women state legislators. Legislative Studies Quarterly, 44(4), 647-80. https://doi.org/10.1111/lsq.12243

Reese, C., \& Warner, B. (2012). Pay equity in the states: An analysis of the gender-pay gap in the public sector. Review of Public Personnel Administration, 32(4), 312-331.

Pew Research Center's Religion \& Public Life Project. (2020). Religion in America: U.S. religious data, demographics and statistics. https://www.pewforum.org/religiouslandscape-study/

Sanbonmatsu, K. (2020). Women's underrepresentation in the U.S. Congress. Daedalus, 149(1), 40-55. https://doi.org/10.1162/daed_a_01772

Sitzmann, T., \& Campbell, E. M. (2020). The hidden cost of prayer: Religiosity and the gender wage gap. Academy of Management Journal. https://doi.org/10.5465/amj.2019.1254

Thomsen, D. (2015). Why so few (Republican) women? Explaining the partisan imbalance of women in the U.S. Congress. Legislative Studies Quarterly, 40(2), 295-323.

U.S. Census Bureau. (2019a). Sex by occupation and median earnings in the past 12 months (in 2019 inflation-adjusted dollars) for the civilian employed population 16 years and older. https://data.census.gov/cedsci/table?q=OCCU PATION\%20BY\%20SEX\%20AND\%20MED IAN\%20EARNINGS\%20IN\%20THE\%20PA ST $\% 2012 \% 20$ MONTHS $\% 20 \& g=0100000 U S$. 04000.001\&tid=ACSDT1Y2019.B24012\&hid ePreview $=$ true.
U.S. Census Bureau. (2019b). Sex by age (American Indian and Alaska Native alone). https://data.census.gov/cedsci/table? $\mathrm{q}=\& \mathrm{t}=\mathrm{Rac}$ e\%20and\%20Ethnicity\&g=0100000US\%2404 00000\&tid=ACSDT5Y2019.B01001C\&hideP review $=$ true.

U.S. Census Bureau. (2019c). Sex by age (Asian alone).

https://data.census.gov/cedsci/table?q=\&t=Rac e\%20and\%20Ethnicity\&g=0100000US\%2404 00000\&tid=ACSDT5Y2019.B01001D\&hideP review $=$ true $\&$ moe $=$ false.

U.S. Census Bureau. (2019d). Sex by age (black alone). https://data.census.gov/cedsci/table?q=\&t=Rac e\%20and\%20Ethnicity\&g=0100000US\%2404 00000\&tid=ACSDT5Y2019.B01001B.

U.S. Census Bureau. (2019e). Sex by age (white alone). https://data.census.gov/cedsci/table?q=\&t=Rac e\%20and\%20Ethnicity\&g=0100000US\%2404 00000\&tid=ACSDT5Y2019.B01001A.

U.S. Census Bureau. (2020). Hispanic or Latino, and Not Hispanic or Latino by race for the population 18 years and over. https://data.census.gov/cedsci/table?q=\&t=Rac e\%20and\%20Ethnicity\&g=0100000US\%2404 00000\&tid=ACSDT5Y2019.B01001C\&hideP review $=$ true.

U.S. Department of Labor Women's Bureau. (n.d.) Equal pay and pay transparency protections. https://www.dol.gov/agencies/wb/equal-payprotections.

U.S. Equal Employment Opportunity Commission (EEOC). (n.d.). Sex Discrimination. https://www.eeoc.gov/youth/sexdiscrimination\#: :text=Title $\% 20 \mathrm{VII} \% 20 \mathrm{prohi}$ bits\%20an\%20employer,traits\%20of\%20a\%2 Oparticular\%20gender.

Volden, C., Wiseman, A. E., and Wittmer, D. E. (2018). Women's issues and their fates in the US Congress. Political Science Research and Methods, 6(4), 679-96.

Whistler, D., \& Ellickson, M. (1999). The incorporation of women in state legislatures: A description. Journal of Women, Politics \& Policy, 20(2), 81-97.

Williams, B., \& Mahoney, J. (2021). State partisan composition. National Conference of State Legislatures. 
https://www.ncsl.org/research/about-statelegislatures/partisan-composition.aspx\#

Wiseman, T., \& Dutta, N. (2016). Religion and the

\begin{abstract}
gender wage gap: A U.S. state-level study.
\end{abstract}
SSRN

Electronic

https://doi.org/10.2139/ssrn.2738523.

Journal 